\title{
Mineral Resources of the Kaliningrad Region
}

\author{
Vyacheslav V. Orlenok ${ }^{*}$ \\ Yevgeny V. Krasnov \\ Valery A.Funtikov \\ Galina N. Chupahina
}

Immanuel Kant Baltic Federal University, Russian Federation *Corresponding Email: VOrlenok@kantiana.ru

Doi:10.5901/mjss.2015.v6n6s7p252

\section{Abstract}

While relatively small in size, the Kaliningrad region has abundant deposits of minerals, many of which are actively exploited (amber, oil, peat, building materials, mineral waters and muds). There are, however, other mineral resources that can be developed here, and some are already being prepared for exploitation (rock salt, potassium and magnesium salts). But any extraction of minerals in a small, economically developed area with unique natural resources requires an assessment of potential risks to the environment. Implementing mine reclamation measures is mandatory. No new fields can be developed without an approval from the community of citizens obtained during public hearings.

Keywords: Kaliningrad region, minerals, nature conservation

\section{Introduction}

The Kaliningrad region (15.1 thousand sq. km, incl. 1.8 thous. sq. km of the Curonian and Kaliningrad / Vistula Lagoons; with the population of 970.6 thous. people as of June 1, 2015 - Socio-economic ... 2015, p. 68) is located in the temperate zones of Europe, in the west of the East European Plain, and lies on the south-eastern coast of the Baltic Sea.

The northernmost point of the region is located in Slavsk district - 55 $19^{\prime} \mathrm{N}$ latitude, the most southern - in the

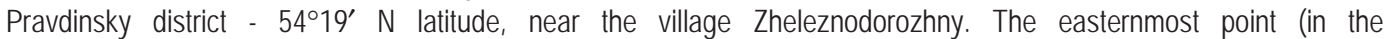
Krasnoznamensk district) is at $22^{\circ} 52^{\prime} \mathrm{E}$ longitute, and the westernmost point - at $19^{\circ} 38^{\prime} \mathrm{E}$ longitude (on the Vistula Spit).

Total length of the regional border is about $540 \mathrm{~km}$, of which $149 \mathrm{~km}$ are on the Baltic Sea coast. In the north and east, the region borders Lithuania; in the south - Poland; and the maritime border is found in the west of the region.

From the geopolitical perspective, the Kaliningrad region is one of the most original subjects of the Russian Federation. After the collapse of the Soviet Union, it became an exclave of the new Russia. One will need to cross the Baltic sea to get from the Kaliningrad region to other regions of Russia without crossing national borders of foreign countries, and a ferry route now operates between the town of Baltiysk in the Kaliningrad region and the port of Ust-Luga in the Leningrad region near St. Petersburg.

The exclave position of the region makes it very expensive to deliver the necessary minerals from the "mainland", so the presence of local mineral deposits means more for the Kaliningrad region than it does for any other region of Russia. The development of local mineral resources increases economic sustainability of the region and provides the economy - at least, partially - with its own base of natural resources (Fedorov, 2011).

\section{Mineral Resources}

The Kaliningrad region is located in the western part of Russian (Eastern European) platform within the southern part of the Baltic syncline. Its crystalline basement is slightly inclined to the west. Sedimentary deposits are also progressively thicker westwards ranging from $1.8 \mathrm{~km}$ in the east of the region near the town of Gusev to $2.6 \mathrm{~km}$ in the west near the town of Mamonovo.

The region's mineral resources may be of limited range, yet they play a significant role in the regional economy. These are, first and foremost, oil, peat, building materials, amber, drinking water, mineral waters, and salt. In addition, 
various repots repeatedly mention brown coal, iron ore, ferrous and rare metals, potassium and magnesium salts, anhydrides, zeolites, and carbonates. However, geological conditions of these deposits, namely, great depth and technical complexity of excavation compared to the deposits in other regions of Russia that are traditionally richer and more readily available for mining, make the development of these raw materials unviable economically and unsustainable (if not dangerous) environmentally (for more details, see: Orlenok, 2002, 2011; Gurevich \& Kazanov, 1976).

Besides, anthropogenic impact on the recreational zone of the Kaliningrad region is very high as is. The main task of modern wildlife management should be to preserve the nature of the region without turning it into a site of mass quarry mining and industrial activity. We should remember that restoration of destroyed landscapes and regaining of ecological balance is much more costly than capital construction projects, and that these efforts can take several generations to complete (Lytvyn, 2004; Krasnov et al., 2004; Orlenok \& Fedorov, 2005).

\subsection{Mineral Resources: Oil}

The search for oil in the Kaliningrad region began in 1955. The first and largest commercial oil field was opened in May 1968 in Krasnoborskoye, 36 kilometers east of the city of Kaliningrad. Currently, oil is produced in 18 out of 26 proven oil fields. In 1983, the USSR received 1.5 million tons of Kaliningrad oil. In the mid-80s, however, due to the natural exhaustion of the fields, oil production started to decline; and by 2003 it dropped to 750 thousand tonnes per year.

In 1963, they began looking for oil in the Baltic Sea. It wasn't too long until two gas fields were found in the Soviet waters: one west of Baltiysk (C-9), and another to the west of the Curonian Spit (D-6). A stationary platform was built on the D-6 field, and in 1984 the very first wells drilled produced the platform's first industrial batch of high-quality light oil. The proven oil field was called 'Kravtsovskoye'. Its two deposits are estimated at 8 million tonnes of oil and 205 million cubic metres of gas, which is comparable to the Krasnoborskoye field with its 9.4 tonnes of oil. The field is developed from ice-resistant platforms. Turning to marine resources allowed to increase production, and in 2009 it exceeded 1.4 million tons. The following years brought about yet another decrease in oil extraction to 1,045 thousand tons of oil and 10 million cubic meters of natural gas in 2012 (Kaliningradstat, 2014; 2015b).

\subsection{Mineral Resources: Rock Salt}

At the moment, there are two proven deposits of rock salt ready for development: one in the vicinity of the town of Gusev and one in the village Romanovo. Since the salt basin underlies a large part of the region's territory, the choice of place for salt extraction and processing is dictated by the need to build underground storage facilities for liquefied gas and sufficient water to scour underground salt formations. Because the Romanovo field is located closer to the primary consumer, and both the quality and capacity of salt deposits are significantly higher than the Gusev field, Romanovo is preferable for pre-production mining of table salt and for the construction of a salt processing plant. Scouring underground salt formations can be done with the sea water pipelined from the Baltic coast. Technical brines can then be discharged at the sea as well. The Romanovo deposit of fresh water can be used in the preparation of table salt and in the construction of underground gas storage facilities. Such a project has already been developed and received an approval from the State Committee on Ecology. A significant part of the raw material can be exported to the Baltic States, Finland, and Sweden, i.e. the countries traditionally importing salt.

\subsection{Mineral Resources: Potassium and Magnesium Salts}

The possibility of production of potassium-magnesium salts near the village Nivenskoye south of Kaliningrad is currently discussed. These salts can be used for the production of agricultural fertilizers. However, local residents are raising concerns of the possible environmental degradations and are expressing stern objections to the prospects of the geological excavations and development so close to the settlement.

Peat. 282 proven peat deposits span 64,553 hectares and have the capacity of 1,906 million cubic meters of peat. There are further 239 fields (53,410 hectares) of less than 20 hectares each. Because each individual field is so small, they are normally not included in the deposit stock reports. Today, peat is extracted for agriculture (it is used as fertiliser and bedding for livestock) and for heating. There are more than 50 fields of fuel peat in the Kaliningrad region, and they have enough capacity to be exploited for decades to come. For this, we need to build a production facility for drying and briquetting of peat. Energy content of peat briquettes reaches $4000 \mathrm{kcal} / \mathrm{kg}$ with $5 \%$ ash content that brings them closer to high-quality Silesian coal $(6000 \mathrm{kcal} / \mathrm{kg}$ ). We need to note, however, that Grachevskoye lignites (sometimes erroneously mistaken for brown coal) have a much lower energy content than peat: $1800 \mathrm{kcal} / \mathrm{kg}$ with a high ash content 
$(45 \%)$ and moisture value of $50 \%$. This means that the lignites cannot be efficiently used to satisfy the popular demand. Boiler houses and power plants use either high-quality coal or work either on high-quality coal or fuel oil, with plans to transition to a much 'greener' gas fuel in the future. Moreover, all calculations show that the cost of lignites is significantly (up to 3 times) higher than the cost of Silesian coal fuel. And let us not forget that peat briquettes have a history in the region: during the World War II, most of the Eastern Prussia was heated this way. We urge the society to pay closer attention to peat extraction and processing industry, especially now that many rural settlements experience shortage of fuel. The development of peat fields, however, can only be carried out if accompanied by a a thorough and comprehensive environmental monitoring.

At the moment, peat extraction in the region is quite low. In 2008 peat production was 36 thousand tonnes, and by 2012that number dropped to 17.5 thousand tonnes (Kaliningradstat, 2014; 2015b).

\subsection{Mineral Resources: Sapropel, Amber, Phosphorites, etc.}

Sapropel is a slimy, dark-brown sediment that is rich in organic carbon. When solidified, it turns into sapropelite, coal shale of high volatility and high hydrogen count. Sapropel is an important chemical raw material, a good fertilizer, and a valuable mineral and vitamin nutrition supplement for livestock. It is also used in medicine. In the Kaliningrad region, sapropel is extracted from the Goreloye, Svinoye, and Klyukvennoye bogs; it used in the various resorts and spas of the region as a healing mud that is especially good for the treatment of radiculitis. Proven industrial sapropel deposits are found in the vicinity of the village Grachevka, in the lakes Brasovo, Goreloye, Smirnovskoye, and Verhkniy Biser.

Amber is fossilized resin of ancient pines. Pieces of amber found in nature come in a variety of sizes: from grainsized, from one to 10 or $20 \mathrm{~cm}$ in diameter. Larger pieces can reach up to 10 kilos in weight. Shapes of the pieces of amber also differ. Some transparent varieties of amber sport inclusions of fossilized insects and plants. Their study helps to recreate the conditions of amber formation and reconstruct the natural environment of the amber-bearing forests.

Baltic amber extraction has its own fascinating history. They used to catch bits of amber with scoop nets from boats, dig it up from the bottom of the sea in shallow waters by poking seabed with sharp sticks, extract it from shallow wells and small pits on the beach. In the mid-1800s industrial mining of amber started in the mining shafts and adits in the vicinity of the village Palmnicken (now Yantarny). In 1912 the first open amber pit was founded near Palmnicken. Apparently, it was quite a success, because its storage facilities discovered near the town of Pillau (now Baltijsk) contained about 0.3 tonnes of amber. Amber was extracted from the so-called 'blue earth' found in the Paleogene deposits.

Exploitation of the Palmnicken pit continued until the 1972, with new bits of land being added to the site on a regular basis since 1948, which guaranteed smooth and uninterrupted mining. Beach deposits turned out to be the richest in amber; these would bring up to $2 \mathrm{~kg}$ of amber per 1 cubic meter of the excavated sediment. These deposits are still being developed through dredging and hydraulic mining. High-power hydraulic jet dislodges the overburden. The water/waste sludge is dumped into the sea through a pipeline. Then, a powerful walking scoop dredge stores the stripped 'blue earth' in cones. A jet mixes amber-bearing earth with water to create a liquid slurry, which the dredger then pipes to the processing plant. About $10 \%$ of amber is lost to transportation.

In 1976 Primorskoye amber field was open for development. At that time, the estimated capacity of the field was evaluated at about 100 years of uninterrupted excavation. The replacement of hydraulic pipeline by the conveyor belt helped to significantly reduce amber losses in the Primorskoye deposit. The planned capacity of the pit is 1,235 tonnes of raw amber per year. The actual production, however, is several times lower.

After treatment and subsequent sorting, the amber arrives at the shop floor of the plant.The largest (ornamental) stones are reserved for jewellery and art pieces. Some pressed amber is used for the same purpose. Most of pressed amber, however, is needed in the production of high-quality insulators for the radio industry. Fine crumbs and larger offgrade amber pieces are dry-distilled (the process is also called 'cracking') and transformed into oils used as solvents in the paint industry, or succinic acid used in the chemical industry and in the production of pharmaceuticals. A by-product of destructive distillation, the so-called 'processed' amber, is further used in the production of high-quality amber varnish.

Illegal extraction of amber is a big problem for many areas of the Sambia Peninsula.Its volumes, according to some experts, are comparable to those reported by the Yantarny amber plant. Administrative measures introduced to stop unauthorized amber mining have so far had very little effect.

Unfortunately, the Kaliningrad region uses only a small fraction of extracted amber for jewellery production.For a long time, the bulk of raw amber was exported to Poland, now it is bought by China.

Phosphorites are the most valuable fertilizer. Nicknamed 'The element of Life and Thought', phosphorus is absorbed by the fruit of plants; therefore, with each harvest, soil is depleted of this element. This is why phosphorus 
needs to be re-introduced into the arable land. Phosphate fertilizers have been around for almost 200 years. Presently, more than 40 million tonnes of phosphate fertilizers a year are used by crop farmers. Every region specializing in agriculture will be lucky to find the deposits of phosphorites.

Paleogenic phosphorites are common in the western part of the Sembia Peninsula, with the biggest deposits in the 'wild land'. At the Primorsky amber pit site alone there are estimated 4 million tonnes of phosphorite deposits, while the numbers for the Pionersky, Mogaikino and Romanovo deposits are deliberately undervalued at, respectively, 2.9, 2.4 and 2.4 million tonnes. Phosphorite is extracted as a side-process of amber mining, but since the issue remains unresolved, the already-extracted mineral, which is highly sought after by the regional farmers, is habitually dumped into the Baltic sea together with the other 'waste'.

Glauconite is a complex raw material. It can be used as a chlorine-free potash fertilizer, cheap dye, adsorbent, technical silica gel, and hard water softener.Like the phosphate-bearing rock, glauconite deposits are typical in the west of the Sambia peninsula, and while no estimates have yet been made, it can be put on the list of amber production sideminerals that are already extracted and then discharged into the sea.

Production of phosphates and glauconites is only possible as a by-process at the Yantarny amber plant quarries.

Construction Materials. Deposits of building materials are, in essence, a part of quaternary deposits. They manifest in small fields that are developed by the locals for their needs. That is not to say that commercial-scale deposits of building materials do not exist, however.

Abrasives are available in the deposits of the Mount Belaya near the root of the Curonian Spit. They are found in the form of renewable garnet-rich placer of ilmenite/zircon type. Preliminary estimates evaluate the field capacity at 45.6 thousand tonnes. Developing renewable placers is an environmentally-friendly enterprise; the Mount Belaya deposit can help produce free garnet grain that can be used for flat glass grinding and garnet sandpaper production.

Deposits of sand and gravel (SGD) are concentrated in the Pregolya river valley in the villages of Berezovka, Ozerki, Pribrezhnoye, Pushkarevo, and Rovnoye. The latter was found to have up to a half of all SGDs of the region, but most of them have been mined by now. Smaller, more modest SGD fields are located in the west of the region.

Deposits of sands are located in Aistovo, Stepnoe, Salskoe, Michurinskoye, Tikhomirovka, and Lesnoe-2. They are largely exhausted and not developed any longer. The newest fields are found in Nemanskoe, Rybachje, Komsomolskoe, and at the $22^{\text {nd }} \mathrm{km}$ of the Curonian Spit (that field is now inactive). Regional deposits of sand are enormous: they have a capacity of more than 4,500 thousand cubic meters per year and a much lower annual extraction rate of less than 3 thousand cubic meters.

Deposits of Clay. The most significant deposits of clay are in the villages of Sokolniki, Druzhba, Lermontovskoe, Prinemanskoe, Frunzenskoe, Yablonevoe, and Telmanovo. Smaller fields are located in Zelenogradsk, Kaliningrad, Chernyakhovsk and Chkalovsk. These fields can give the region at least 300 years worth of clay. The largest of these is the Sokolniki field, located $6 \mathrm{~km}$ southwest of Zelenogradsk. Clay can be used to manufacture conventional and hollow brick, drainage pipes, clay gravel that replaces natural gravel and pebbles in concrete mix.

Rubble excavation in 2013 was 309 thousand cubic meters, excavation of sand was 3,555 cubic meters, and gravel - 40 thousand cubic meters (Kaliningradstat, 2014; 2015b).

More than 20 deposits of building materials are currently developed in the region. The extracted raw materials are delivered to brick factories, construction organizations, concrete and construction panel manufacturers, structural engineering companies.

\section{Conclusion}

The capacity of mineral resources in the region exceeds current exploitation efforts, while the share of mining industry in the region's economy is decreasing. In 2009 the industry accounted for $7.3 \%$ of gross regional product, and by 2012 its share had dropped to $4.8 \%$ (Kaliningrad... 2014, p. 21). Moreover, the volumes of production at competitive prices decreased (primarily due to the decrease of oil production). The number of mining companies was reduced from 63 to 44 (only 12 of which produce fuel and energy sources: oil and peat); the volume of products manufactured in-house amounted to 15.3 billion roubles in 2013. (Kaliningradstat, 2015a). The development of new fields requires significant long-term investment, which is difficult to attract, and doubly so during the times of an economic crisis. What is more, development of mineral resources on a small territory with unique natural reserves requires careful planning for mitigating possible environmental impact. It also needs a plan for mine reclamation, which increases the cost of new mining projects and, in most cases, hinders the development of new fields. 


\section{References}

Fedorov, G.M. (2011). Socio-Economic Development of the Kaliningrad Region, IKBFU Press.

Gurevich, G.I., \& Kazanov, Yu.V. (1976). Mineral Resources of the Kaliningrad Region, Kaliningrad: Kaliningradskoye Kn.Izdatelstvo.

Kaliningradstat (2014). Kaliningrad Region in Figures. Report. Part 2. Kaliningrad.

Kaliningradstat (2015a). Social and Economic Situation in the Kaliningrad Region in the First Half of 2014. Report. Operative information. Kaliningrad.

Kaliningradstat (2015b). Kaliningrad Region in Figures. Report. Part 2. Kaliningrad.

Krasnov, Ye.V., Blazhchishin, A.I., \& Shkitsky, V.A. (2004). Ecology of the Kaliningrad Region, Kaliningrad: Yantarny Skaz.

Lytvyn, V.M (2004). Essays on the Nature of the Kaliningrad Region, (ed.). Kaliningrad: Yantarny Skaz.

Orlenok, V.V. (2002). Geography of the Kaliningrad Region: an Atlas, (ed.). Kaliningrad: Kaliningrad State University Press.

Orlenok, V.V. (2004). Geography of the Russian Amberland, (ed.). Kaliningrad: Yantarny Skaz.

Orlenok, V.V. (2011). Atlas of the Kaliningrad Region. Kaliningrad: IKBFU Press.

Orlenok, V.V., \& Fedorov G.M. (2005). Regional Geography of Russia. The Kaliningrad region. Kalinngrad: State University of Russia Press. 